\title{
A Native American Technology Transfer: The Diffusion of Potato
}

\author{
Charles R. Brown \\ U.S. Department of Agriculture-Agricultural Research Service, Irrigated Agriculture Research and Extension
Center, Washington State University, Prosser, WA 99350-9687
}

HISTORY

Potato (Solanum tuberosum L.) deserves merit as one of the most important foods of the world, as well as a notable example of dissemination to the rest of the world of a crop domesticated solely by native South Americans. It was unknown to Europeans until the onset of exchanges between the two hemispheres that commenced after the voyages of Christopher Columbus. Even though samples of potato are thought to have arrived in Spain around 1570, and Spanish chroniclers were writing of its huge contribution to the sustenance of Andean civilizations even before it was introduced to Europe as a botanical curiosity, the potato remained a poorly understood plant for nearly a century. These writings were in many cases not available until modern times, long after potato became a staple on the continents to which it was introduced. An example of this is the large tome of Don Felipe Huamán Poma de Ayala, written in 1584-1614, entitled Nueva Crónica y Buen Gobierno. This was one of the most detailed narratives of life in Peru after the establishment of Spanish rule. The author, a Peruvian native raised and educated by Catholic clergy, sent his manuscript to the Spanish king as a 1400-page document complete with numerous sketches (Fig. 1). However, it was little noticed and probably never seen by the king, for it was taken by the Danish ambassador to Denmark where it was completely forgotten for three centuries, until it was discovered in the Royal Library of Denmark in 1908. Certainly, the strange journey of this most informative record prevented Europeans from being properly informed of the potential of the potato, which remained a plant enigma all too long. It described potato cultivation and the importance of it as a foodstuff in the context of the agriculture of the day. The author was born before the Spanish conquest and the existence and ingestion of potato was neither strange nor noteworthy to him; thus, he listed it along with other crops. Several sketches depicted the planting and harvesting of potato and removal of the harvest to storage buildings, and allusions were made to different cultivars and their particular place in the agricultural production system (Fig. 1).

José de Acosta, who traveled in South America from 1571 to 1576 , wrote:

In the elevated region of the Sierra of Peru the provinces which they call the Collao, composing the greater part of that kingdom, where the climate is so cold and dry that it will not permit the cultivation of wheat or maize, the Indians use another kind of roots which they call Pappas, a kind of turmas de tierra that send up scant foliage. These pappas they collect and leave in the sun to dry well, and breaking them they make what they call chunyo which will keep for food in that form many days and serves them for bread; and of this chunyo there is great commerce in that kingdom with the mines of Potosí. Pappas are also eaten fresh either boiled or from one of the mildest varieties which also grows in warm situations they make a certain ragout..." (Acosta, 1880, edited version).

Nonetheless, potato arrived as an unknown immigrant and remained so in Europe for at least a century. In one of the first attempts to describe the potato plant, Bauhin (1596) wrote:

\footnotetext{
Received for publication 16 July 1998. Accepted for publication 1 Dec. 1999. The cost of publishing this paper was defrayed in part by the payment of page charges. Under postal regulations, this paper therefore must be hereby marked advertisement solely to indicate this fact.
}
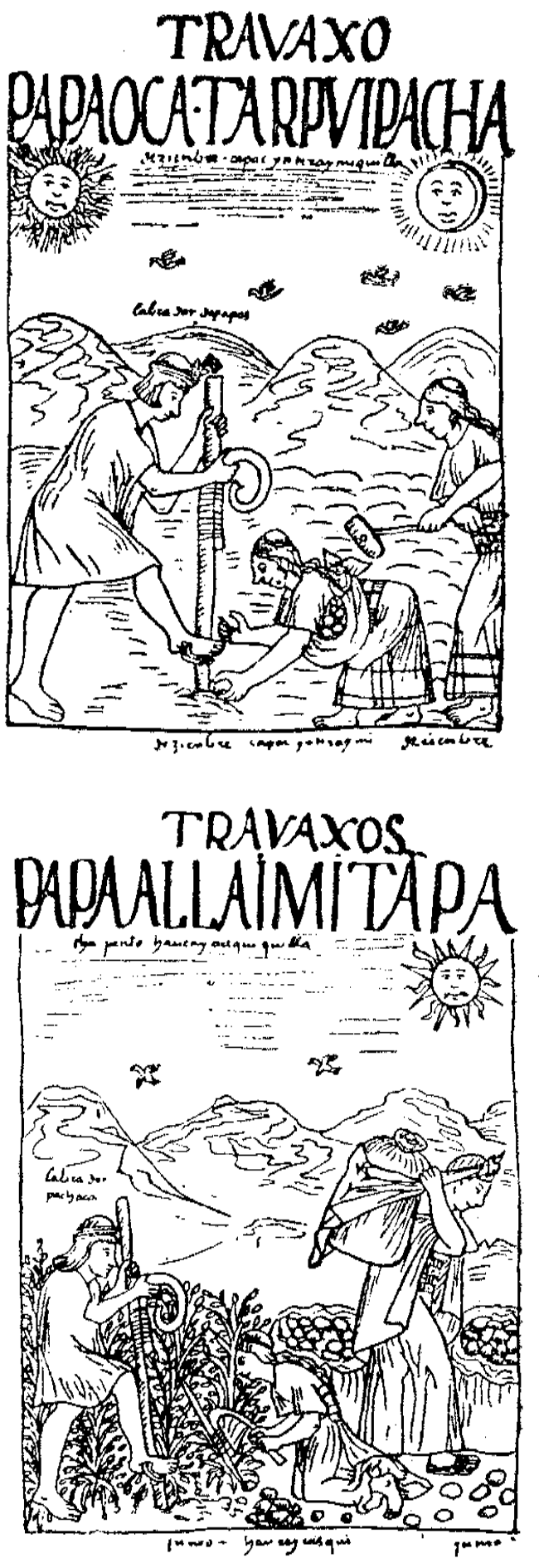

Fig. 1. Sketches from Huamán Poma's (1944) Nuevas Cronicas y Buen Gobierno depicting (top) the planting of potato using the Andean foot plow (chaquitaqulla), a tool which is still in use today, and (bottom) the harvesting and transport of potatoes in bags carried on the back. This pictorial representation of everyday life was not available until the 20th century, despite the best efforts of the author. 
The root is of an irregular round shape; it is either brown or reddish-black, and one digs them up in the winter lest they should rot, so full are they of juice. One puts them in the earth once more in spring: should it happen that one leaves them in the sun, in the springtime they will sprout of themselves. Further at the base of the stem close to the roots there spring long fibrous radicles on which are borne the very small round roots. The root itself generally rots when the plant is fully developed. We have judged it our duty to call this plant Solanum by reason of the resemblance of its leaves with that of tomato, and its flowers with those of the Aubergine, its seed with that of Solanums and because of its strong odor which is common to these latter. It is called by some the Pappas of the Spanish and by other the Pappas of the Indies. We have further learned that this plant is known under the name of Tartouffoli, doubtless because of its tuberous root, seeing that this the name by which one speaks of Truffles in Italy where one eats these fruits in a similar fashion to truffles.

The application of the descriptor "truffle" apparently stuck, as potato is known as the similar sounding "Kartoffel" in German and Russian and by variants of this in other languages in Europe. But, it was Bauhin (1596) who first called potato Solanum tuberosum esculentum, the last term of which was deleted by Linnaeus to conform to his binomial system. The English word potato is derived from "patata," which referred to sweet potato. Interestingly, the native Quechua word "papa" is used today only in Spanish-speaking areas of the New World.

A misconception persisted for years that potato was brought directly from the Virginia colony to England through the aegis of Sir Walter Raleigh. According to our modern understanding, there were no potatoes in Virginia. Potatoes went directly to Spain and then were passed around the Continent, arriving in England at the beginning of the 17 th century. The lack of a warm reception at first was undoubtedly because potatoes from low latitudes of South America produced very little tuber yield in the long summer days in Europe's higher latitude. There is no clear proof of this, but sexually produced progeny arising from these first introductions must have had genetic variation for tuberization stimulus under long days. Native South American cultivars tuberize poorly or not at all in long photoperiods, presenting a strong barrier to direct utilization, even today. The morphology discernible in the first drawings of potato lends credence to the theory that the introduction was of short-day adapted S. tuberosum ssp. andigena Hawkes, perhaps obtained on the Atlantic coast of presentday Columbia (see Fig. 2). The relatively short transit to Spain would make it highly feasible to introduce potato by this route (Hawkes, 1978). Russian taxonomists, however, noting that modern long-day adapted cultivars resemble Chilean cultivars, once classified as $S$. chilotanum Hawkes, have long maintained that the potato must have been introduced from southern Chile where long-day adaptation already existed (Bukasov, 1986). Hawkes (1990) chose not to include S. chilotanum as a valid taxon in his most recent summary of the biosystematics of potato. The argument that long-day European potato cultivars were more likely to have originated from preadapted Chilean ancestors has won more than Russian scientists to its side, and remains a question of great interest. However, whatever the route by which the potato may have arrived in the Old World, once it had an appropriate daylength response and began to give a respectable tuber yield, its adoption as a "second bread" proceeded directly. It is not too farfetched to surmise that population increases in certain areas of Europe and certainly in Ireland were due in some part to the potato adding to the agricultural wealth of Europe (Davidson, 1992; Hobhouse, 1986).

After the European introduction, potato was transformed from an inconsequential and puzzling hobby plant to the mainstay diet of many countries over two centuries, yet there were few further introductions of germplasm from its center of origin. The concept of breeding of plants developed slowly, only really taking off in the 19th century. The idea of returning to the center of origin to enrich the gene pool is a modern concept, and had little importance for most of the 19th century.

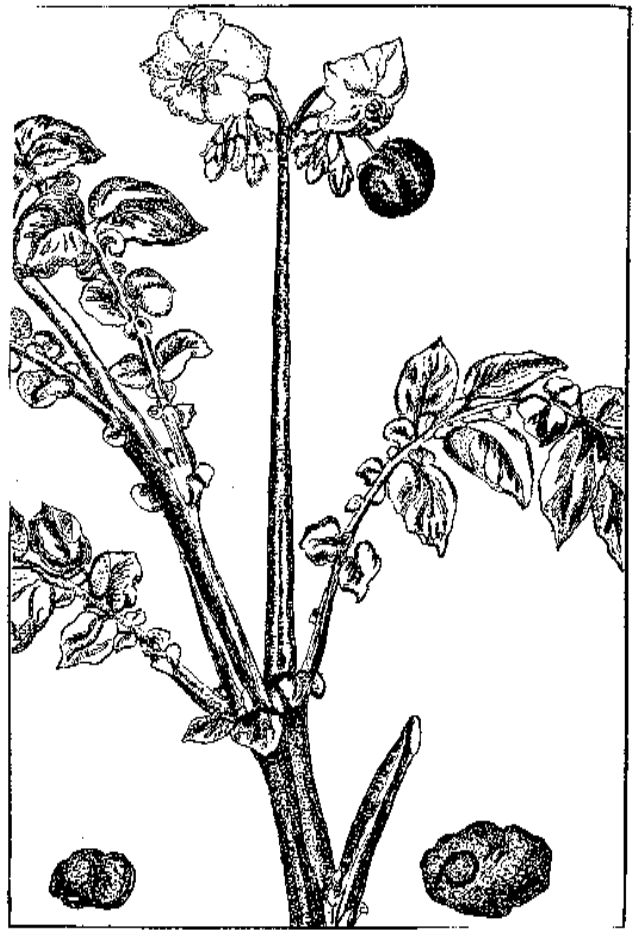

Fig. 2. One of the first drawings of potato sent to Clusius by Phillippe de Sivry, Prefect of Mons, in 1589. The well-dissected leaves, large, well-developed inflorescence, and small tubers argue persuasively that the original European introduction was the short-day adapted Solanum tuberosum ssp. andigena.

\section{Evolution of Cultivated Potatoes}

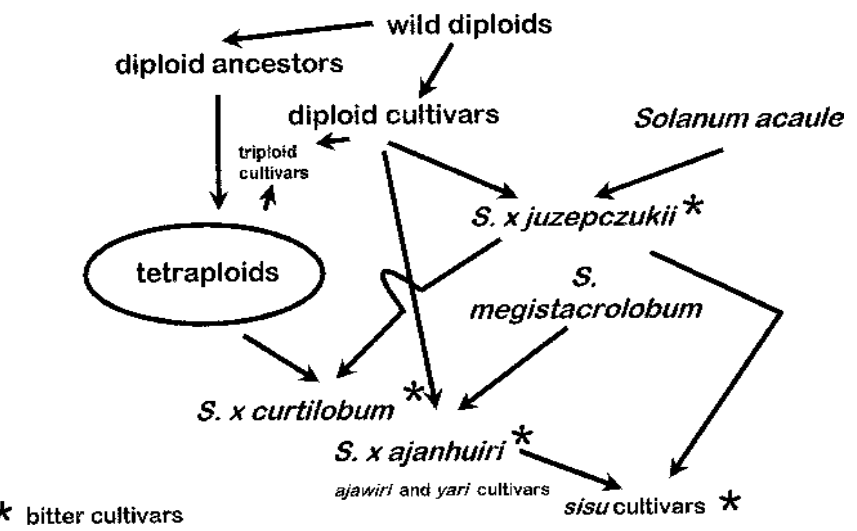

Fig. 3. A simplified diagram of the evolution of potato. The bitter potatoes derive their frost resistance from $S$. acaule and $S$. megistacrolobum. The tetraploid species Solanum tuberosum ssp. andigena is by far the most important cultivar; $75 \%$ of cultivated potatoes collected are of this subspecies. Diploid cultivars, at $16 \%$ of the total, make up an important, but less widespread and diverse group. Perú is by far the richest source of distinct accessions (see Table 1).

The importation of potatoes from South America by the Rev. Chauncey Goodrich of New York in 1861 led to the development of very influential germlines that later gave rise to 'Early Rose' and the still highly important 'Russet Burbank'. In the 20th century, organized plant exploration led to the first understanding of the biosystematics of tuber-bearing Solanum and the first comprehensive assessment available to the world at large of the rich diversity of cultivars, which number in the thousands. 


\section{NATIVE CULTIVARS: BITTER POTATOES AS A SOLUTION TO FROST}

Considerable potato production occurs in the high Andes. In these settings, the single most important constraint is night frost during the growing season. Due to the nearly equal length of day and night in equatorial and near-equatorial locales, high elevation and certain climatological factors cause night temperatures to fall below freezing at various times during the growing season. The risk of freezing is greatest at the higher elevations and the subfreezing temperatures usually persist for a few hours before dawn. Under the most frostconducive conditions the temperature can easily drop to $-5{ }^{\circ} \mathrm{C}$, and these sudden killing frosts can occur any time during the growing season. To address this, Andean farmers have domesticated so-called bitter potato (papa amarga). Taxonomically, bitter potatoes consist of several groups: Cultivars of $S$. ×juczepzukii Juz. and Buk. and $S$. $\times$ curtilobum Juz. and Buk. are specialized as frost-resistant cultivars by virtue of being hybrids with the wild species $S$. acaule Bitt., a wild tetraploid species with exceptional frost tolerance found at extremely high elevations. Cultivars of S. ajanhuiri Juz. and Buk. differ in that the frost tolerance is theorized to derive from the wild progenitor, $S$. megistacrolobum Bitt. In field experiments, exposure to $-5^{\circ} \mathrm{C}$ resulted in the death of $100 \%$ of the foliage of the cultivar Ccompis (Solanum tuberosum ssp. andigena) while $S$. ×juzepczukii, S. ×curtilobum, and S. ajanhuiri suffered 5\%, 30\%, and 40\% damage, respectively (Huanco, 1991). The frost tolerance of bitter potatoes means the difference between survival and starvation.

The $S$. ajanhuiri complex is cultivated and widely known in the Bolivian Altiplano, especially in the province of Pacajes (Department of La Paz) and some adjacent areas in the Department of Oruro. It is also grown around Lake Titicaca in both Peru and Bolivia. The species is divided between two groups denoted by names in the Aymara language. Of the two morphotypes of $S$. ajanhuiri, Yari, the most primitive, possesses bitter and non-bitter cultivars while Ajawiri types are considered relatively more advanced and palatable. The reduced bitterness of Ajawiri cultivars gives them a comparative advantage in marketability compared to the more frost-tolerant Yari cultivars. Field studies have indicated that there is a gradient of morphology between the wild ancestor and the $S$. xajanhuiri cultivars, which may be explained by hybridization that has occurred between cultivated and wild potato. In addition, there is a poorly understood group of nonbitter cultivars classified under the general name of Sisu. Johns (1990) has postulated that these cultivars, which possess striking frost tolerance, are hybrids of Yari or Ajawiri cultivars with $S$. ×jucepczukii. The $S$. ajanhuiri complex, by virtue of its fertility, has probably served as a conduit for wild genes into the cultivated gene pool (Fig. 3). The occurrence of frost-tolerant non-bitter members throughout this group is evidence that high levels of glycoalkaloids are not necessary for frost tolerance. Rather, glycoalkaloids probably reflect the presence of large portions of wild genome in the cultivars, which are themselves direct hybrids with wild progenitors or one generation removed from cultivated types by backcrossing.

Among the frost-resistant cultivars, the bitterest ones must be processed to reduce the content of bitter glycoalkaloids before making the edible dried product "chuño." The potatoes are crushed with the foot and allowed to freeze outside overnight to disrupt cell structure (Fig. 4). Subsequently, the tissue is soaked in water to leach out the glycoalkaloids and then set in the sun to dry. The finished product can be stored indefinitely, and is reconstituted with water for soups and stews. Because of its storability, transportability, and nutritional value, chuño captured the attention of the writers of the first commentaries of the early Spanish conquerors. The newly arrived Spanish entrepreneurs set about to buy chuño at a low price from producers and transport it to the mines (e.g., Postosí), where it was sold at a much inflated price as a food for the workers, all of whom were enslaved natives (Salaman, 1985).

Among the frost-resistant bitter potatoes, some excellent cultivars have been selected that yield up to $40 \mathrm{t} \cdot \mathrm{ha}^{-1}$. Of these, the glycoalkaloid contents may reach $490 \mathrm{~g} \cdot \mathrm{kg}^{-1}$ fresh weight, although many cultivars have lower levels. Processing to remove these glycoalkaloids unfortunately removes about two-thirds of the protein, making chuño a much depleted food compared with fresh potato (Huanco, 1991). There is evidence that the intensity of the bitter taste conferred by the glycoalkaloids has been reduced by native peoples of the altiplano by cooking the bitter potatoes with certain kinds of clay. This form of consumption, termed geophagy, provided a technological bridge for the domestication of potatoes resistant to frost, because frost resistance was linked to high glycoalkaloid content. Experiments have shown that the clays employed adsorbed the glycoalkaloids, sequestering them as bound toxicants. Geophagous consumption was also accompanied by attempts of selectors to find less bitter or non-bitter clones, something that is quite evident in the Yari and Ajawiri cultivars present today that need no processing to be eaten (Johns, 1990).

\section{TETRAPLOID POTATOES: THE GREAT DIVERSITY RESERVOIR}

In modern times, native non-bitter cultivars are found primarily in rural locations. The tetraploid potatoes are the most diverse, widespread, and highest yielding. The tetraploid Solanum tuberosum ssp. andigena is therefore a mainstay where frost is not limiting (Fig. 3). Fully $75 \%$ of the International Potato Center's World Collection is $S$. tuberosum ssp. andigena (Table 1). To a certain extent, the native cultivars are in competition with modern cultivars, yet their appeal is

Table 1. Geographic coverage and number of distinct accessions of cultivated Solanum species conserved in the genebank at the International Potato Center (CIP), Lima, Peru (Huamán et al., 1997).

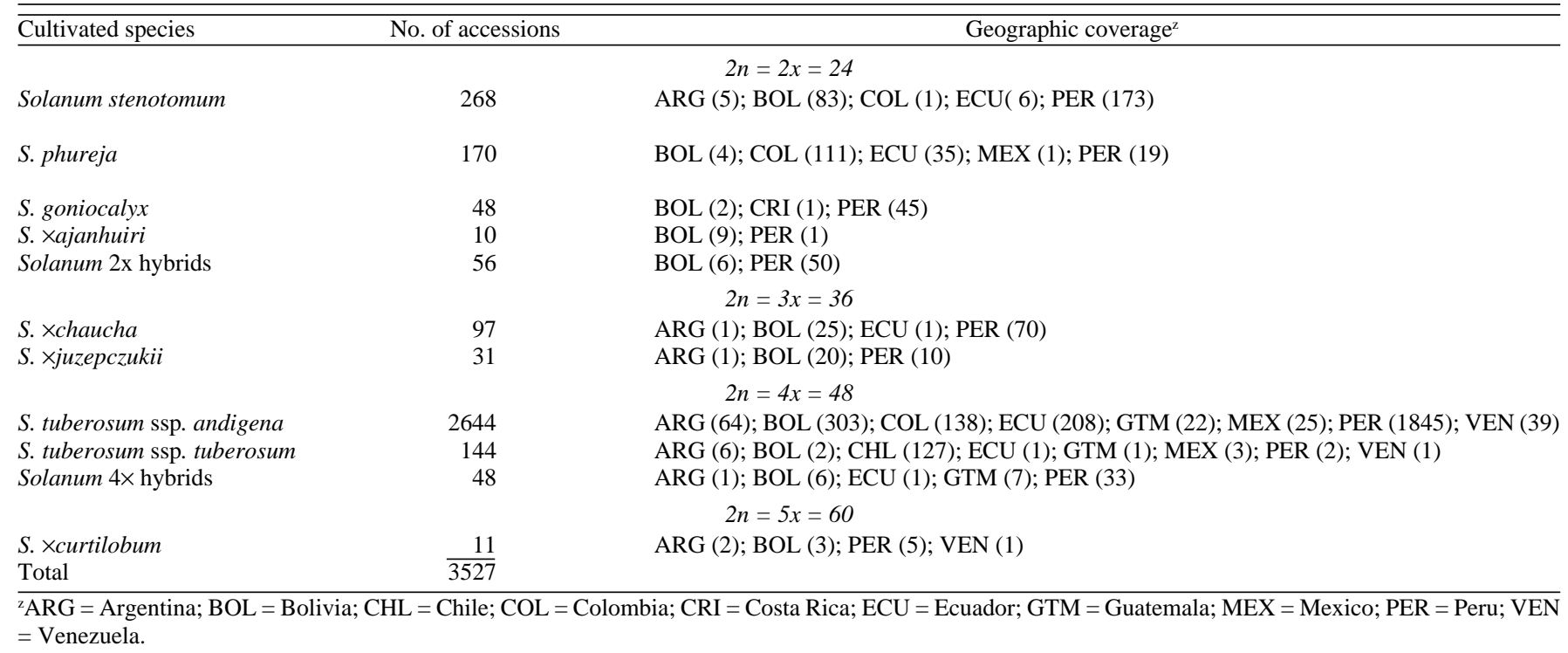



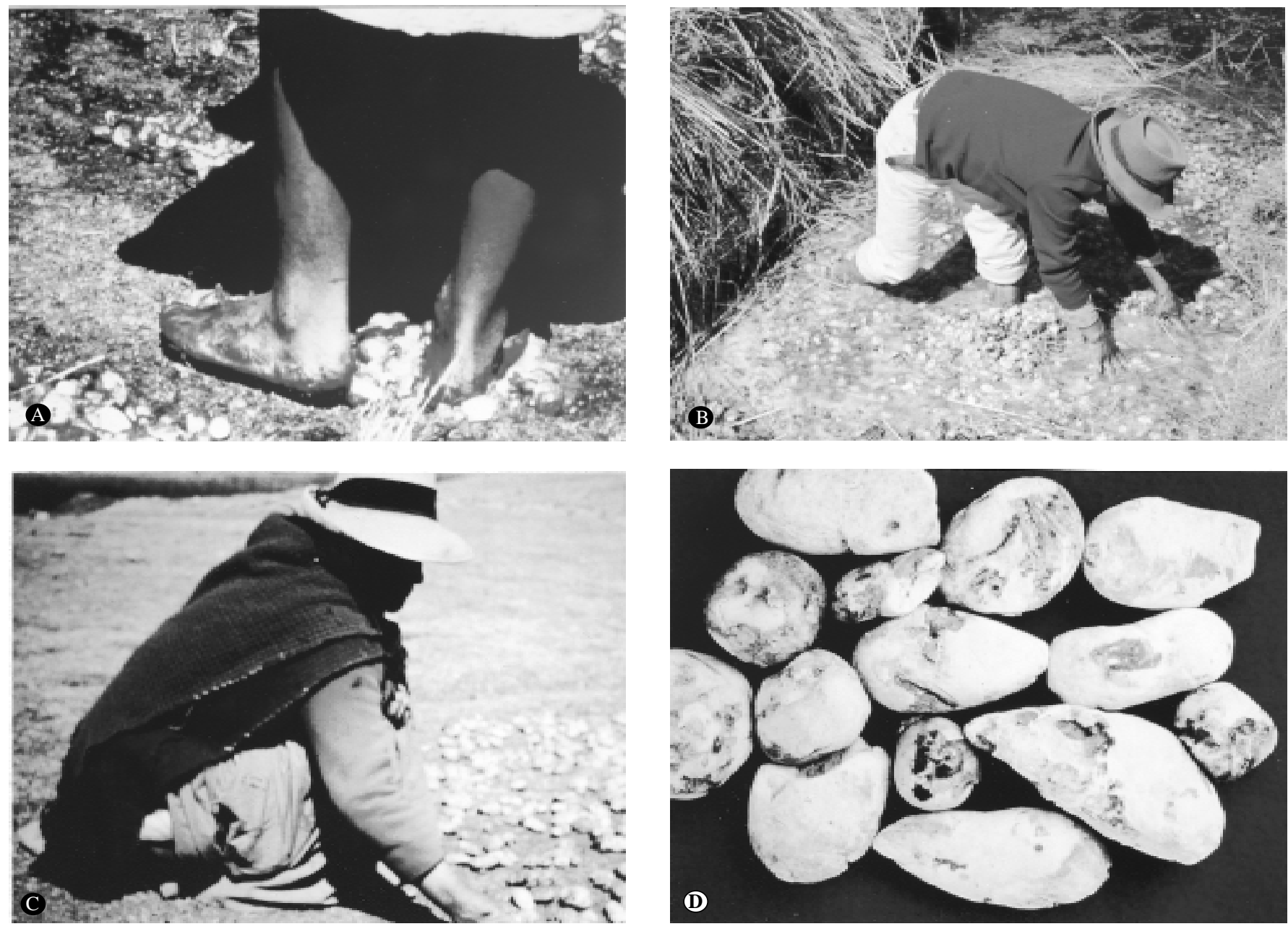

Fig. 4. The processing of bitter potatoes into the non-bitter dried product chuño. (A) Crushing to disrupt cell structure and freezing outside overnight, (B) soaking in water to leach out glycoalkaloids, (C) drying in the sun, and (D) the finished product. Photo: International Potato Center.

still retained because they are prized for their culinary traits. Thus, a rural household may grow a modern-bred cultivar, papa aguanosa (watery potato) or papa blanca (white potato), for sale to city markets because the return for agronomic inputs is higher, whereas the old traditional cultivars, papa de regalo (gift potato) or papa de color (colored potato), will be retained for home consumption or sale of surplus in the local markets (Christiansen, 1967) (Fig. 5 and cover photograph of this issue).

Johns (1990) described a folk taxonomy among the Aymara of the Bolivian altiplano. The highest level is ch'oke, which circumscribes cultivated potatoes that are edible after boiling (non-bitter). Underneath this level, frost-resistant potatoes that are bitter are referred to as $l u q^{\prime} i$, and wild potatoes are denoted as apharu. At high elevations, the average number of cultivars grown per household is 10 and men and women farmers can name and distinguish as many as 32 cultivars, although the naming is not necessarily consistent among individuals (Johns, 1990).

A detailed examination of two mixed fields in southern Peru identified 26 distinct cultivars, five of which were diploids, three triploids (not bitter types), and the remainder tetraploids (Solanum tuberosum ssp. andigena) (Quiros et al., 1990). Another study near Cusco in southern Peru revealed that a field may contain 10 to 30 native cultivars, averaging 20. Out of 28 mixed potato fields sampled, 79 cultivars, which could be further separated into 164 subcultivars, were distinguished. One-third of the 79 cultivars were cosmopolitan in being found across three distinct regions, whereas the rest were restricted in distribution, and were in certain cases limited to only one or two fields over the whole sampling area (Zimmerer, 1991). Potato folk nomenclature reflects considerable sophistication in differentiation by morphology and use in the household economy. Comparisons of biochemical genetic markers and local names indicate a high degree of correspondence between farmer identification and genotype, although, occasionally, similar-appearing but genetically different varieties are classed as one variety by farmers. Not too surprisingly, among the interviewees there were "botanist" farmers with an acute sense of genetic diversity and complex systems for identifying and naming numerous cultivars, and others for whom potato consisted only of one or two general types.

Potato cultivars are classified, according to their method of preparation, as being more suitable for boiling, in soups, as mashed potatoes, for specialized yellow-flesh dishes, or bitter potatoes for processing into chuño (frost-resistant cultivars). Cultivar names, often in the Quechua or Aymara languages, are descriptive of: 1) appearance, e.g., "cat's face," "black girl," "llama's tongue," "puma's paw"; or 2) function, e.g., "potato for fever" or "potato for weaning of children from mother's milk" (Brush, 1980).

The wild potato species $S$. jamesii Torr. and S. fendleri Asa Gray are consumed with clay by certain Native American tribes of the American Southwest. Navajo, Zuni, and Hopi gather potatoes in the wild, and cook them with clays (as with the examples of geophagy cited for the Bolivian Altiplano) with the expressed purpose of preventing the stomach pains and vomiting that occur when large quantities of bitter potatoes are ingested (Laufer, 1932). These potatoes are treated mostly as wild plants that are gathered in times of famine, but the Tarahumara people of Chihuahua may transplant them and maintain them in fields.

An example of a nontoxic wild species that is eaten is $S$. cardiophyllum Lindl., which grows as a weed in maize fields in San Luis Potosí and Aguascalientes, Mexico. It is low in glycoalkaloids and is harvested and sold in local markets as papita güera (little white potato). 

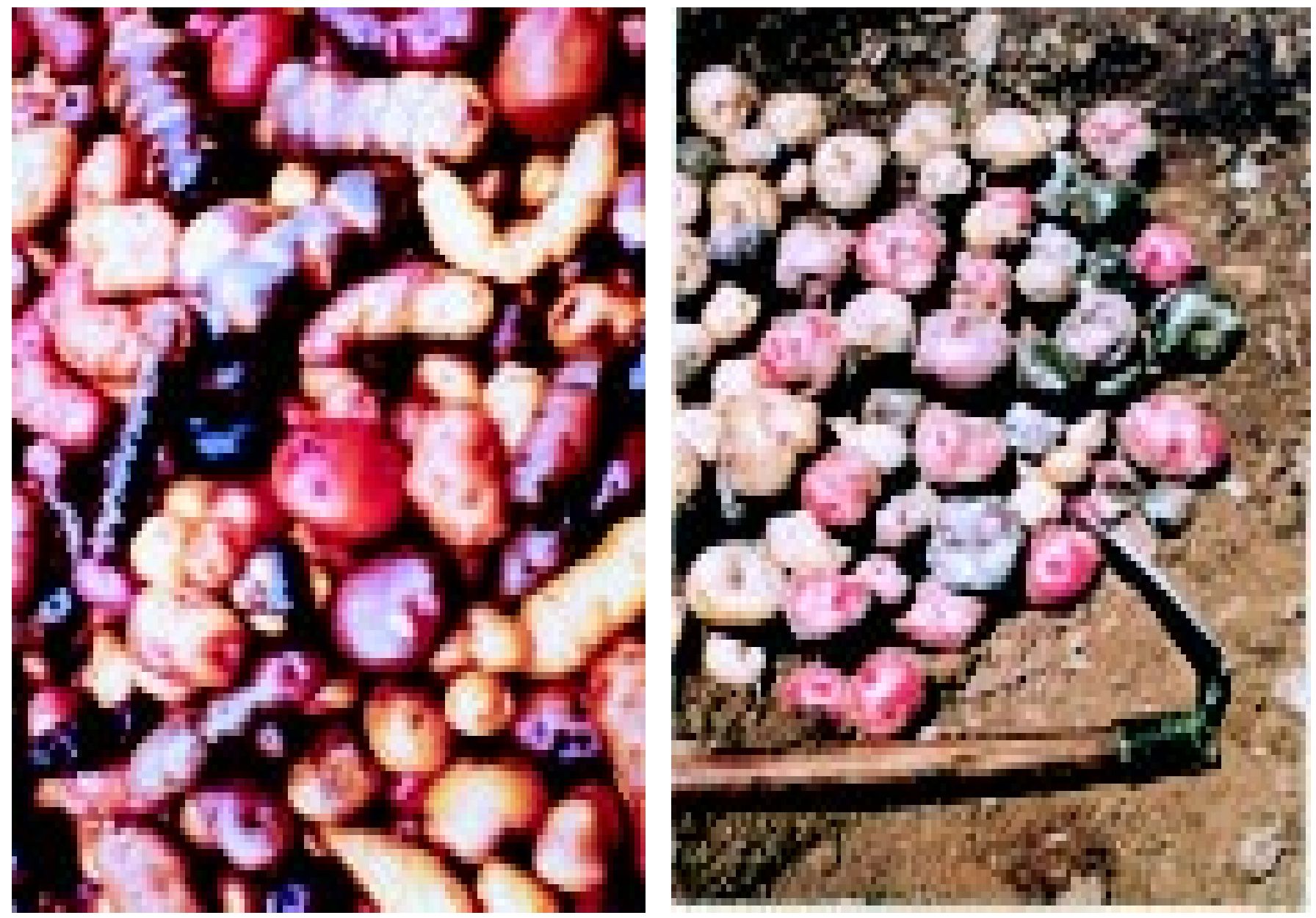

Fig. 5. (left) A sample of the morphological variation of potato tubers in the World Collection of Cultivars at the International Potato Center. (See cover of this issue.) (right) Mixture of different potato cultivars found in a single farmer's field in the Cañete Valley of Perú. Photos: International Potato Center.

The rich diversity of potato cultivars in South America, in its center of origin, is a man-made accomplishment, the credit for which goes to native peoples past and present. The solution to frost presented by the bitter potatoes is a masterful use of wild species and shows the ability of native people to cope with a difficult abiotic limitation with a compromise cultivar that also presents palatability challenges. The widespread existence of tetraploid cultivars in great profusion and great quantity throughout the range of potato in the Andes demonstrates the creative plant-breeding abilities of native peoples who selected and preserved not only a good food, but also imbued this with an astonishing array of visually stimulating skin colors and shapes. In partnership with the genetic potential of the tuber-bearing Solanum, native Americans have given the world a truly health-promoting and civilization-sustaining food.

\section{Literature Cited}

Acosta, José de. 1880. The natural and moral history of the Indies. (First published in Spanish in 1590.) From a 1604 English translation edited by Clements R. Markham. The Hakluyt Society. Vol. 60. Burt Franklin, New York.

Bauhin, G. 1596. Phytopinax. Basel, Switzerland.

Brush, S.B. 1980. Potato taxonomies in Andean agriculture, p. 37-47. In: D.W. Brokensha, D.M. Warren, and O. Werner (eds.). Indigenous knowledge systems and development. Univ. Press of America, New York.

Bukasov, S.M. 1986. Systematics of potato, p. 1-40. In: A.Y. Kameraz (ed.). Systematics, breeding and seed production of potatoes. Bul. Appl. Bot. Genet. Breed. 62:(1). (Translation from Russian published by A.A. Balkema, Rotterdam, The Netherlands.)

Christiansen, J. 1967. El cultivo de la papa en el Perú. Published privately. Talleres de Artes Gráficas de Editorial Jurídica, Lima, Perú.

Davidson, A. 1992. Europeans' wary encounter with tomatoes, potatoes, and other New World foods, p. 1-14. In: N. Foster and L.S. Cordell (eds.). Chilies to chocolate: Foods the Americas gave the world. Univ. of Arizona Press, Tucson.

Hawkes, J.G. 1978. History of the potato, p. 1-14. In: P.M. Harris (ed.). The potato crop: The scientific basis for improvement. Chapman and Hall, London.

Hawkes, J.G. 1990. The potato: Evolution, biodiversity, and genetic resources. Smithsonian Inst. Press, Washington, D.C.

Hobhouse, H. 1986. Seeds of change. Harper Row. New York.

Huamán, Z., A. Golmirzaie, and W. Amorós. 1997. The potato, p. 21-28. In: D. Fuccillo, L. Sears, and P. Stapleton (eds.). Biodiversity in trust: Conservation and use of plant genetic resources in CGIAR centres. Cambridge Univ. Press, Cambridge, U.K.

Huamán, Z., J.G. Hawkes, and P.R. Rowe. 1980. Solanum xajanhuiri: An important diploid potato cultivated in the Andean altiplano. Econ. Bot. 34:335-343.

Huamán Poma de Ayala, F. 1944. Nueva crónica y buen gobierno (written between 1584 and 1614). A. Poznansky (ed.). Inst. Tiahuanacu de Antropología Etnografía y Prehistoria, La Paz, Bolivia.

Huanco, V. 1991. Potencial de las papas amargas en el altiplano de Puno, Perú, p. 25-26. In: J. Rea and J.J. Vacher (eds.). La papa amarga. I Mesa Redonda: Perú-Boliva, La Paz, 7 y 8 de Mayo, 1991. Orstom, La Paz, Bolivia.

Johns, T. 1990. With bitter herbs they shall eat it: Chemical ecology and the origins of human diet and medicine. Univ. of Arizona Press, Tucson.

Laufer, B. 1938. The American plant migration. Part I: The potato. Field Mus. Natl. Hist. Anthrop. Ser. Vol. 28(1). Publ. 418. Chicago.

Quiros, C.F., S.B. Brush, D.S. Douches, K.S. Zimmerer, and G. Huestis. 1990. Biochemical and folk assessment of variability of Andean cultivated potatoes. Econ. Bot. 44:254-266.

Salaman, R.N. 1985. The history and the social influence of the potato. Revised impression. J.G. Hawkes (ed.). Cambridge Univ. Press, Cambridge, U.K.

Zimmerer, K.S. 1991. The regional biogeography of native potato cultivars in highland Peru. J. Biogeography 18:165-178. 